\title{
Mutaties in de redactie
}

Prof. Dr. S.W. Douma

In de samenstelling van de redactie van het MAB hebben zich enkele wijzigingen voorgedaan. De heren Prof. Dr. J.L. Bouma, Prof. Dr. M.A. van Hoepen en Prof. Dr. Ir. R. Maes zijn op 30 september j.I. uit de redactie getreden. In de daardoor ontstane vacatures is voorzien door de benoeming van Prof. Dr. A.W.A. Boot. Prof. Dr. M.N. Hoogendoorn en Prof. Dr. J. Theeuwes tot lid van de redactie.

Prof. Dr. J.L. Bouma is in 1966 toegetreden tot de redactie. Sedert 1985 was hij naast lid van de redactie ook voorzitter. Gedurende de negenentwintig jaar waarin Bouma aan het $\mathrm{MAB}$ verbonden is geweest. heeft hij in zeer belangrijke mate bijgedragen aan het blad. Hij heeft dat gedaan in verschillende hoedanigheden: als auteur, als redacteur en als voorzitter van de redactie. De artikelen die van zijn hand in het MAB zijn verschenen bestrijken een breed spectrum van de bedrijfseconomie. De onderwerpen waarover hij, dikwijls alleen en soms ook met één of meer coauteurs, schreef zijn: kostprijs en toeval, herziening van conversiekoersen, de betekenis van bedrijfsspelen voor het onderzoek van het gedrag van organisaties, bedrijfseconomie en toepassing van $k$ wantitatieve methoden, multinationale marketing, de vermaatschappelijking van de onderneming, financiële innovaties, het CAPM als walarderingstheorie, ontwikkelingen in de externe verslaggeving, ontwikkelingen in management accounting, de markt voor vennootschappelijk bestuur, beleggen in beleggingsfondsen en de teloorgang van een gemeentelijke kredietbank. Daaruit blijkt een brede belangstelling die veel verder gaat dan het terrein van de financiering. Als redacteur van het $M A B$ heeft Bouma vele anderen aangemoedigd een bijdrage te schrijven voor het $\mathrm{MAB}$ en talloze artikelen beoordeeld en van kritische opmerkingen voorzien. Als voorzitter van de redactie heeft Bouma het blad met vaardige hand geleid. Hij heeft een klimaat weten te scheppen waarin initiatieven konden worden genomen en waarin velen bereid waren zich in te zetten zoals hij dat zelf ook deed. Zo heeft het $M A B$ zich tijdig aan veranderende omstandigheden kunnen aanpassen. Tenslotte heeft Bouma steeds de kwaliteit van het blad zorgvuldig bewalakt. Het is uiteindelijk aan de voorzitter van de redactie om te beoordelen of een bepaald artikel wel of niet in het MAB zal worden geplaatst. Ieder artikel dat ter publikatie aan het $\mathrm{MAB}$ wordt voorgelegd wordt door meerdere leden van de redactieraald beoordeeld. Deze beoordelingen helpen de voorzitter van de redactie bij het vellen van het finale oordeel. Niettemin is het de voorzitter van de redactie die de uiteindelijke beslissing neemt. Bouma heeft deze verantwoordelijkheid ruim tien jaar gedragen. Daarbij heeft hij nimmer een concessie gedaan aan de kwaliteit.

Prof. Dr. M.A. van Hoepen is vanaf 1985 lid geweest van de redactie. Ook hij heeft in het MAB meerdere artikelen gepubliceerd, onder meer over de presentatie in de jaarrekening van de belasting over de schijnwinst op vaste activa, over discriminantanalyse en de accountantsverklaring bij de jaarrekening van ondernemingen met continuïteitsproblemen en over fiscale eenheid en jaarrekening. Daarnaast heeft Van Hoepen een groot aantal boekbesprekingen en een viertal columns met een geheel eigen stijl verzorgd.

Prof. Dr. Ir. R. Maes is vanaf 1984 lid van de redactie geweest. Hij publiceerde in het MAB 
naast een drietal columns een artikel over beslissingstabellen in kritisch perspectief. Van Hoepen en Maes zijn voor het MAB als redacteur van grote waarde geweest. Het werk dat een redacteur van het MAB doet onttrekt zich voor een groot deel aan de ogen van buitenstaanders. Het betreft niet alleen het beoordelen van artikelen maar ook het signaleren van nieuwe ontwikkelingen op het vakgebied waarin de betrokken redacteur is gespecialiseerd. Daarbij is signaleren van nieuwe ontwikkelingen uiteraard niet genoeg. Een goede redacteur neemt ook initiatieven om anderen aan te sporen om over die ontwikkelingen te schrijven. Van Hoepen en Maes hebben in dit opzicht ruimschoots hun bijdrage geleverd.

De drie in de redactie ontstane vacatures zijn, zoals gezegd, opgevuld door de benoeming tot redacteur van Prof. Dr. A.W.A. Boot, Prof. Dr. M.N. Hoogendoorn en Prof. Dr. J. Theeuwes. Boot is hoogleraar Financiering aan de Universiteit van Amsterdam, Hoogendoorn is hoogleraar
Externe verslaggeving aan de Universiteit van Amsterdam en Theeuwes is hoogleraar Bedrijfskunde in het bijzonder bestuurlijke informatievoorziening aan de Technische Universiteit Eindhoven. Ondergetekende is benoemd tot voorzitter van de redactie.

Als nieuwe voorzitter van de redactie wil ik gaarne mede namens de andere leden van de redactie en de redactieraad en vooral ook namens de lezers van het MAB de collegae Bouma, Van Hoepen en Maes dank zeggen voor de bijdragen die zij aan de kwaliteit van het MAB hebben geleverd. De heren Boot, Hoogendoorn en Theeuwes heet ik van harte welkom in de redactie.

Zo lang ik mij kan herinneren is het MAB het toonalangevende blad geweest op het gebied van de accountancy en de bedrijfseconomie. Dat is het onder Bouma's leiding altijd geweest en dat zal het ook in de toekomst blijven. 